\title{
Outpatient Clinic in Ancient Greece
}

George SAMONIS a, Christos KOUTSERIMPAS ${ }^{b}$, Maria-loanna RANTOUc, Marianna KARAMANOU d, Manolis I. STEFANAKIS

${ }^{a}$ Department of Medicine, University Hospital of Crete, Heraklion, Greece

${ }^{b}$ Department of Orthopaedics and Traumatology,

"251" Hellenic Air Force General Hospital of Athens, Greece

'Attorney-at-law, LLM. Doxatou str 2, Filothei, 115237, Attiki, Greece

${ }^{\mathrm{d}}$ Department of History of Medicine and Medical Ethics, Medical School, National and Kapodistrian University of Athens, Greece

eDepartment of Mediterranean Studies, University of the Aegean, Rhodes, Greece

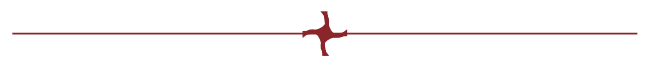

\begin{abstract}
- ABSTRACT
Introduction: Several sciences, including medicine, have their origin in Ancient Greece. It is intriguing to comprehend how Ancient Greek physicians were practicing medicine. The present study evaluates the role of an Ancient Greek physician in an outpatient clinic by examining the first depiction of such a clinic in Western history which is painted on the surface of a red-figured rounded small vase (aryvallos).

Methods: An Ancient Greek aryvallos painted c. 480-450 BC, now on display at the Louvre museum, was meticulously studied regarding its painted surface, which presents an outpatient clinic in Ancient Greece. Other Ancient Greek works of art presenting medical activities have been also evaluated in order to reach informed conclusions regarding medical practice of that period.

Results: The aryvallos depicts a physician performing bloodletting in a patient. Another five males, four of them with traumas holding canes are waiting their turn. Among them, a dwarf holding a hare on his shoulder can be seen. Suction cups on the wall and a copper basin on the floor for blood collection are also included in the picture.

Discussion and conclusion: The aryvallos depicts the earliest known realistic scene of medical service in Western history. All previous Ancient Greek scenes which dealt with relevant themes, invariably included "holy" and divine interventions. Trauma management, as well as bloodletting seem to form part of the everyday medical practice of that time, while gifts to physicians (one of possible explanations of the dwarf's hare, which is depicted on the aryvallos scene) were common. Additionally, historical sources reveal that Ancient Greek physicians were well-paid and much respected. Medicine has always been an honorable practice throughout the centuries.
\end{abstract}

Keywords: Ancient Greece, medicine, bloodletting, physician in Ancient Greece, aryvallos, outpatient clinic.

\footnotetext{
Address for correspondence:

Dr C. Koutserimpas

Department of Orthopaedics and Traumatology, "251" Hellenic Air Force General Hospital of Athens, Greece

Postal address: Kanellopoulou Av 3, 11525, Athens, Greece

Tel: 0030 6948712130, email: chrisku91@hotmail.com, ORCID: 0000-0002-1398-9626
}

Article received on the $18^{\text {th }}$ of October 2021 and accepted for publication on the $10^{\text {th }}$ of December 2021 


\section{INTRODUCTION}

T he $21^{\text {st }}$ century AD finds medicine in a turning point. After a fast evolution during the $20^{\text {th }}$ century, medical sciences are now in a state of explosion, deciphering molecular mechanisms by adopting novel revolutionary techniques (1). The acceleration of medical knowledge during the last 150 years was the end-stage of a period lasting for centuries. The first steps of medicine in the Western world took place in Ancient Greece, starting early during the archaic era and evolved further, during the classical period (1).

Hippocrates was the first physician who studied anatomy thoroughly and, by observation, made an effort to understand the human physiology (2-5). He adopted for the first time rational, realistic and practical approaches for healing traumas, wounds and diseases (1-4). The pre-Hippocratic era was characterized by beliefs of divine intervention either for causing or healing diseases (6-8).

Achievements of Ancient Greece represent the dawn of the western civilization, including the birth of several sciences (5). It is therefore fascinating to understand how Ancient Greeks practiced medicine, by using several historical sources.

The present study represents an effort to understand the role of an Ancient Greek physician practicing medicine in the setting of an outpatient clinic of that time, by examining a unique depiction of such a clinic on the surface of an Ancient Greek red-figured vase (aryvallos) (9-11).

\section{METHODS}

A Ancient Greek small rounded vase (aryvallos) painted c. 480-450 BC, by the so-called "painter of the clinic", now exhibited in the Louvre museum in Paris, was meticulously studied regarding its painted surface, which depicts an outpatient clinic in Ancient Greece.

Other Ancient Greek works of art presenting medical activities have been also studied and compared to the aryvallos' presentation, in order to extract conclusions regarding medical practice as it evolved during the period dominated by the Ancient Greek civilization.

\section{RESULTS}

The Louvre aryvallos, painted c. $480-450$ BC by the so-called "painter of the clinic", provides

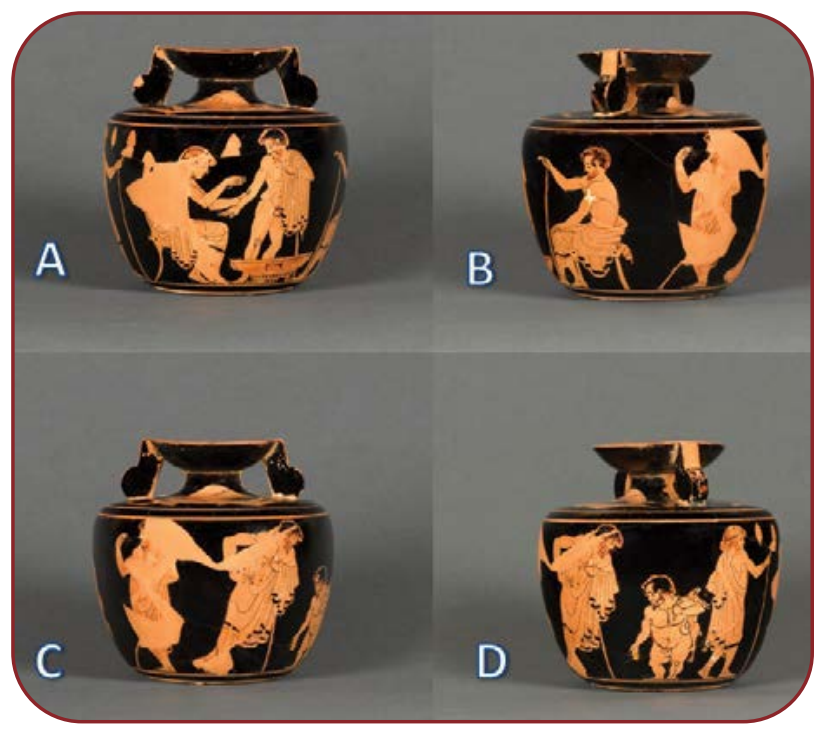

FIGURE 1. A-D. Red-figured aryvallos (Paris, Musée du Louvre: CA2183) ca. 480-470 BC, depicting an outpatient clinic in Ancient Greece (printed with permission. Photo $\odot$ RMN-Grand Palais (Musée du Louvre)/Stéphane Maréchalle)

unique information about medical practice of that time (Figure 1).

The red-figured painted surface of this small vase depicts an outpatient clinic where a practicing physician appears to be taking care of his patients. In particular, a young physician of light complexion is depicted in sitting position using a small type of lancet, to cause bloodletting from a vein of the right arm of an almost nude, standing, bearded man with dark hair, who supports himself with a cane which he holds with his left hand (Figure 1A). The patient is staring at the surgical instrument with an expression that can be described as awe and anxiety, while a copper basin for blood collection lays on the floor in front of the patient.

The vase painting, expect the physician and patient treated by bloodletting, includes another five male figures. On the right side of the patient there is a sitting, nude above the waist, bearded, male figure with dark hair. His right hand is horizontally raised holding a vertical cane, while his left one is resting on his knee (Figure 1B). A bandage can be seen covering his upper arm. Another dressed, also bearded male figure, with dark hair, is standing behind him, raising his right hand in a gesture, as if he addresses the physician. A bandage covers part of his left arm. It can be as- 
sumed that the two latter men are awaiting their turn to be examined. An additional bearded, also dressed man with dark hair is standing behind the previous one. He stands and is crossing his feet. He has his right hand in his waist and is leaning to the left, supported by a crunch (Figure 1C). This last figure is looking down at a bearded nude dwarf who carries a hare on his shoulder (Figure 1D). Finally, after the dwarf there is another man, dressed, this time without beard and of light complexion, who appears to be moving supported by a cane towards the rear of the sitting physician. A bandage covers part of his left leg.

On the wall, above the sitting physician, three suction cups can be seen: two on his left and one on his right side (Figures 1A, 1D).

\section{DISCUSSION}

T he depiction

The painted surface of this red-figured aryvallos depicts the earliest known realistic scene of medical service in Western history, showing a practicing physician taking care of patients.

Archaeologists believe that the picture describes a medical outpatient clinic c. 470 BC (9-11). Up to that time, all known Ancient Greek depictions of medical practice, treatment and/or therapeutic interventions represented the idea of "holy" treatment and included divine figures, such as Asclepios or Amfiaraos, who were considered divine figures protecting 'Hygeia' (Ancient and Modern Greek word for "health") that was often presented also as goddess $(8,12,13)$.

Realistic medical representations were for centuries rare in Ancient Greek art and, in any case, depictions were not as detailed as the present one, making the scene of the aryvallos unique and of utmost importance regarding the information of everyday medical practice of the era that can be extracted from it (14).

The scene: the examination room and the medical instruments

The aryvallos painter, who is known among archaeologists as the "painter of the clinic", has also designed the furniture of the room, namely the physician's chair and what could be considered as the equivalent of a sofa, where one of the patients is sitting awaiting his turn. Additionally, a basin for blood collection on the floor is also presented in detail. The three suction cups on the wall, give an

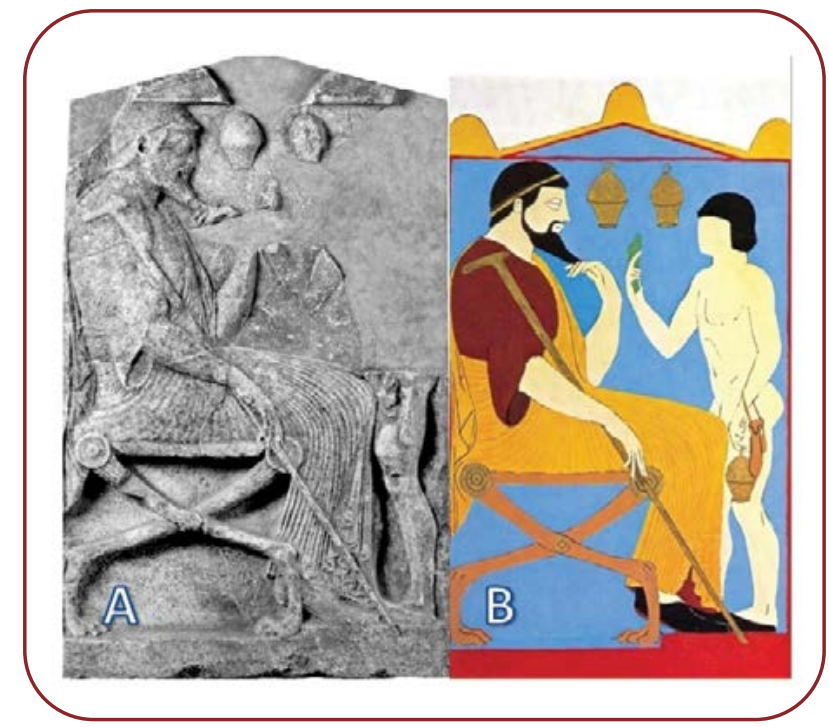

FIGURE 2. Funerary stele of a physician from the Greek-Ionian coast of Asia Minor (Bale, Antikenmuseum, inv. no. BS 236). A) reprint from Hillert A.

Antike Ärztedarstellungen (Marburger Schriften zur Medizingeschichte 25), Frankfurt am Main 1990, 70-75

(Kat. ${ }^{\circ} 3$ ), pl. 9; B) drawing of the stele with colour $<$ https://anaskafh.arsakeio.gr/hygeia_astheneia_b/>, accessed 01/11/2021.

idea of medical instruments used at the time and also create the impression of a three-dimensional perspective of the room, since they are designed at the background. Similar suction cups can be found in certain other works of art of the same period (14-16). In particular, such instruments can be seen in the background of a tombstone monument (epitimvios stele) of a physician from the Greek lonian coast of Asia Minor, exhibited now in the museum of Basel, Switzerland (16). This bas-relief presents the dead physician sitting and, in front of him, his young assistant holding such a cup ready to be used (Figure 2). It can therefore be reasonably assumed that these instruments were widely used by physicians in Ancient Greece. It is interesting to note that similar instruments were traditionally used in some Mediterranean countries up until some decades ago.

\section{The use of the aryvallos}

This type of small vases (aryvallos) was extensively used in Ancient Greece. Most times their contents were liquids of small quantity and high quality, namely perfumes, oils used by athletes for treatment of their skin or medical drugs $(7,11)$. Given the depiction of the clinic, it can be assumed that the present aryvallos' content was of medical use. 
Other depictions of medical scenes of that era No other such scene of an organized medical service (outpatient clinic) is known to have been painted on an Ancient Greek ceramic of that era. A votive offering of the same era (c. 475 BC) found in the temple of Amfiaraos in Oropos, near Athens, now in the Archaeological Museum of Athens, is a bas-relief presenting a sleeping patient having a "holy" dream revealing the patient's treatment, through the help of the holy snake of the god Asclepios $(8,14)$. Interestingly, this sculpture depicts on the same surface both sides of the concept of medicine as it was understood in Ancient Greece: on the one hand, the "holy" treatment: divine and apocalyptic through "holy" dreams and on the other hand, the realistic/medicinal treatment: the physician takes care of a patient's shoulder in his capacity as a doctor. The anonymous sculptor has created a room where the two methods, the divine and the realistic, coexist. Indeed, the sculpture depicts a bed where the patient sleeps dreaming the divine intervention (in the back of the room), whereas in the front of that same room the physician is seen applying practical treatment. An inscription on the wall mentions the divine grace (Figure 3A).

Similar pictures of healing by divine intervention through dreaming are not rare in Ancient Greek art. Such a scene is presented for instance in a bas-relief, also a votive offering to the Asclepieion (both a holy institution, and a hospital dedicated to god Asclepios) of Piraeus, now in the archaeological museum of that city (14). In particular, the scene depicts a sick woman lying asleep on a bed, while the god Asclepios is treating her. Next to him stands Hygeia (Health), presented as divine figure. At the other end of the room, three relatives of the patient are waiting, appearing to expect the outcome of the holy intervention (Figure 3B).

\section{The practice of bloodletting}

With regard to the practice of bloodletting which, as mentioned above, is depicted on the Louvre aryvallos by the "painter of the clinic", this had been a common practice in Ancient Greece. It was actually a known therapeutic method even before the time of the "clinic" depicted on the aryvallos' surface (c. $470 \mathrm{BC}$ ), but became more common in later centuries, when it was widely introduced by Gallinos, the most celebrated Ancient Greek physician after Hippocrates $(17,18)$. Gallinos was born in the Greek city of Pergamos in Asia Minor in $129 \mathrm{AD}$. His theories were based on those of Hippocrates but were improved further, fending off completely the then-traditional ideas of divine interventions and holy dreams. He applied reasonable therapeutic techniques based on human anatomy, which was meticulously studied by both Hippocrates and Gallinos (14).

\section{The practice of wound treatment}

As mentioned above, the "clinic painter" also presents on the aryvallos three men with recent

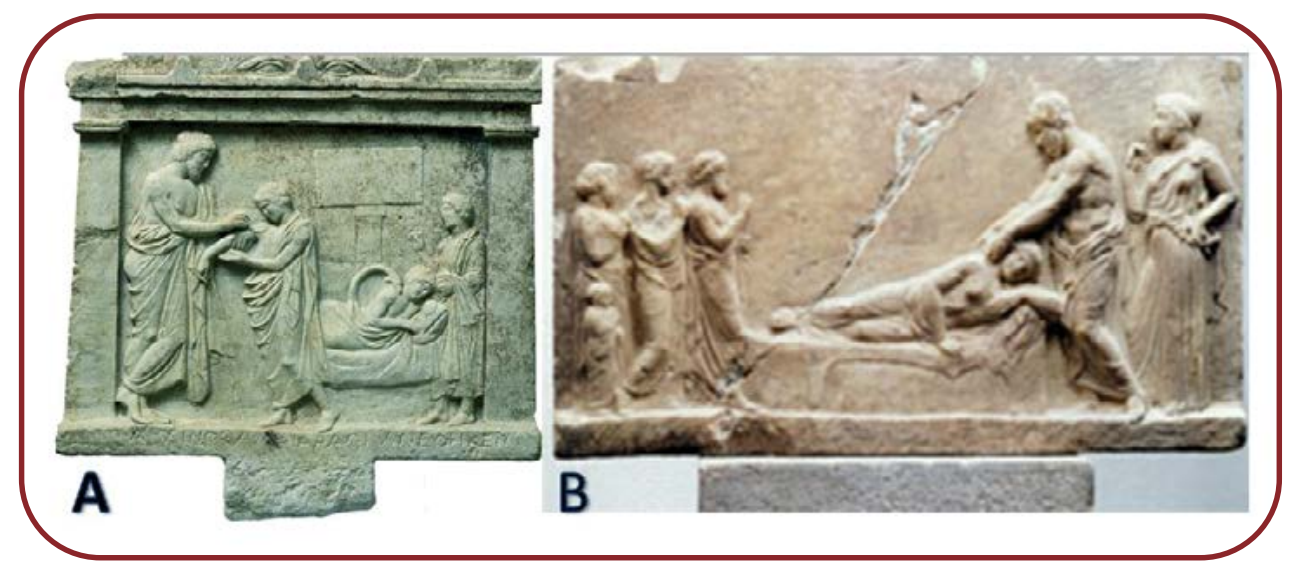

FIGURE 2. A) Temple-like votive relief depicting Asclepius treating the shoulder of a young man. The patient is also shown in the background asleep, while the holy snake tends to the wounded shoulder (first half of the fourth century BC). From the Archeological Museum of Athens. B) Relief depicting Asclepius providing treatment to a recumbent patient (circa 400 BCE). From the archeological museum of Pireus, Greece (reprint from Falagas ME, Zarkadoulia EA, Bliziotis IA, Samonis G. Science in Greece: from the age of Hippocrates to the age of the genome. FASEB J 2006;20:1946-50). 


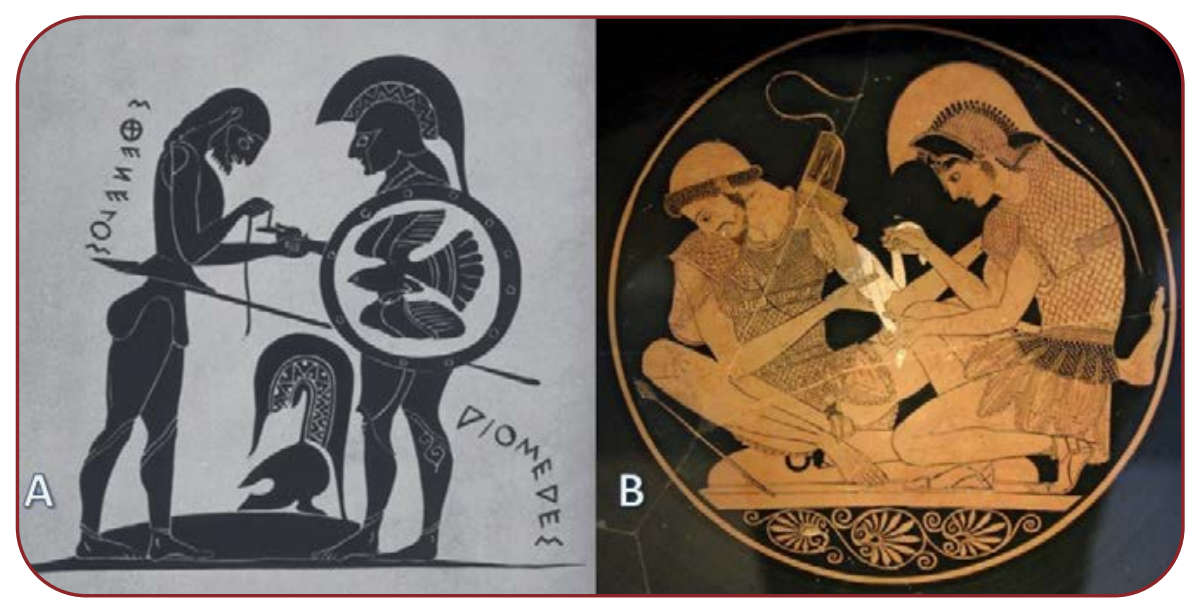

FIGURE 4. Depiction of wound treatment in Ancient Greece. A) Sthenelos bandaging the wounded finger of Diomedes. Ink drawing after a Chalcidian neck-amphora circa 550 BC (Edited in black and white). Credits to 'Wellcome Library, London'. Copyrighted work available under CC-BY Attribution 4.0 International license. B) "the cup (kylix) of Voulci" from Southern Italy, now in Altes Museum in Berlin. Achilles taking care of the wound of Patroclus. Used under the Creative Commons CCO License

trauma, covered by clean white bandages. Two of them have wounds in their arms, while the third one in a leg. These appear to be minor injuries, which have presumably already received first aid, either from the present physician or somebody else, and the patients are currently waiting a follow-up visit (Figure 1).

Wound treatment was a well-known medical procedure in Ancient Greece. It is first described by Homer in lliad, during the war of Troy. Many types of wounds are mentioned by Homer, as well as their treatment (19-21). Many of those wounds were lethal, while others, either severe or minor, were described to have been treated with great care, using clean water, air stream and several herbs and remedies, by the Greek army physicians Machaon and Podalirius (22-23).

Depiction of wound treatment on either black-or-red-figured vases is not rare in Ancient Greece. The first known representation was depicted on the surface of a now lost amphora, made c. $550 \mathrm{BC}$ in southern Italy (a region also known as Magna Grecia). The lost black-figured ceramic depicted two Homeric heroes mentioned in Iliad: Sthenalos taking take of a wound in the hand of Diomedes (Figure 4A).

Another depiction of wound treatment, unique regarding its artistic value, appears on the surface of a well-known masterpiece, the kylix (cup) of Voulci, also from Southern Italy, now in
Altes Museum in Berlin. This kylix was made by the potter Sossias and probably painted by Kleofradis (Figure 4B). It is a red-figured Attic (Athenian-style) cup made c. 500 BC. On the surface of this kylix, one can observe Achilles taking care of the wound on the arm of his close friend and fellow warrior Patroclus. Achilles can be seen covering the wound with a bandage, after Patroclus had been wounded by an arrow in a battle during the siege of Troy. The painting is remarkable for the detailed depiction, the positions, as well as the expressions of the two heroes and the bandaging of Patroclus' trauma, providing information about similar trauma care of the era.

It is worth noting that the depictions on the above-mentioned vases (ie, the amphora and the kylix) are inspired by mythical episodes taking place in the battlefield and represent first-aid offering or in situ help. On the contrary, the Louvre aryvallos depicts a well-organized outpatient clinic of the classical era.

\section{The role of the dwarf of the clinic}

Amongst the well-shaped male figures, the scene depicted on the aryvallos also includes a dwarf who carries a hare on his shoulder. Dwarfs were usually presented in Ancient Greek art as achondroplastic beings (24-25). In a similar vein, the "dwarf of the clinic" is presented in a very naturalistic manner, with massive trunk, short legs, thick 
thighs and a head and face with typical features of achondroplasia (Figure 1D). His genitals are "infibulated" (infibulation is the use of a leather thong around the foreskin of the penis, pulling it upwards and finally tied around the waist), a practice quite common among athletes of the era (26). Although the dwarf has been often considered by archaeologists as being the physician's assistant, one could also assume that he could be a patient, since achondroplasia can be complicated with pain of the lower extremities and the back, needing medical attention (27).

Several assumptions can be made based on the study of the male figures of the "clinic". The status of most of them, such as that of the physician and the four patients, as well as their roles and expectations, appear straightforward, leading to rather definitive conclusions. However, the presence of the dwarf, especially the interpretation of the hare that he carries on his shoulder allows for speculation. Is the dwarf the physician's assistant? Is the hare a gift, given to the assistant by one of the men who are seeking medical attention? Or is the dwarf himself a patient, bringing the hare as payment or gift? There is no clear assumption or conclusion and, hence, the role of the dwarf remains uncertain.

\section{Compensation or gift-giving in return of medical services}

The presence of the hare, as possible "payment" brings up the issue of payment for medical services provided in Ancient Greece. Historical sources of the time the aryvallos was made, suggest that physicians were paid with money, but a gift could be also welcomed as a gesture of gratitude, a habit which still exists in most Mediterranean countries (26). According to the celebrated Athenian theatrical author Aristophanes, during the fifth century BC, physicians were among the best paid professionals, not only in Athens but all around the Ancient Greek world $(28,29)$. In most cases they were public servants and the city was responsible for covering their salary. Early enough, around 600 BC, the regulations of Harondas, a famous legislator of Katane, an important Greek city on the island of Sicily, provided that all citizens had to be covered by a kind of public healthcare system. Hence, the city-state would employ physicians to cover the citizens' medical needs. It is believed that a well-established physician in the classical era was receiving about 500 drachmas per year, throughout the Greek world (30). For centuries, since the Homeric era, the medical profession was highly appreciated, much respected and well paid. In particular, according to
Homer's Iliad a physician's life was considered most valuable, since he could save several warriors' lives during and after a battle $(19,31)$.

Conclusions regarding the medical profession in Ancient Greece

As regards the medical profession in Ancient Greece, one can observe many similarities to the present time. Indeed, in addition to physicians-public clerks, there were other physicians offering their services on a private practice basis, paid directly by their patients. Highly skillful physicians were sought by several cities offering them many benefits and high salaries. Such an example is the case of Demokides, a famous physician of the Greek city of Kroton in Southern Italy, in the sixth century BC, who was invited to work on the island of Aegina receiving 17 drachmas per day. Later on, the city of Athens offered him twice this amount in order to move and work there as public health provider $(30,32)$. In order to understand the value of such salaries, it suffices to consider that, during the same period, a highly skillful craftsman working in the construction of the Acropolis of Athens was paid with 1-2 drachmas per day (33).

In light of the above, it is clear that, looking back throughout the centuries, the medical profession has always been respected, and physicians received generous compensation and special benefits. The respect shown to them, required physicians to bear great responsibilities and always demonstrate high moral values. Indeed, serving "Hygeia" (Health) was considered a divine gift. These duties and responsibilities are detailed and well-described in the Hippocratic Oath, a text that exemplifies even today the Ancient Greek spirit. This is also the reason why the Hippocratic Oath still remains as relevant today as it was 2500 years ago: it provides the canvas that lays down the rules of exemplary medical practice throughout the ages. $\square$

Conflicts of interest: none declared.

Financial support: none declared.

Authors' contributions: GS, CK, MIR for the literature search and analysis and manuscript writing. MK and MIS for the final manuscript revision. All authors have read and approved the final manuscript.

Acknowledgments: This work has been done in honor of Dr. Nikolaos Stampolidis, Professor of Archaeology, the University of Crete, Rethymnon, Greece. 


\section{$\gamma$}

\section{R}

1. Pulciani S, Di Lonardo A, Fagnani C, Taruscio D. P4 Medicine versus Hippocrates. Ann It Super Sanita 2017;53:185-191.

2. Desai J, Sadrieh K. It's Time to Remember Hippocrates. I Child Neurol 2018;33:501-502.

3. Jouanna, J. Hippocrates. The John Hopkins University Press, Baltimore and London 1999.

4. Schiefsk M. Hippocrates on Ancient Medicine. Brill Academic Publishers, 2005.

5. Falagas ME, Zarkadoulia EA, Bliziotis IA, Samonis G. Science in Greece: from the age of Hippocrates to the age of the genome. FASEB J 2006;20:1946-50.

6. Yapijakis Ch. Hippocrates of Kos, the father of clinical medicine, and Asclepiades of Bithynia, the father of molecular medicine. InVivo 2009;23:507-514.

7. Laskaratos IG. History of Medicine. Athens: Paschalidis CP, Medical Publications Ltd, 2004.

8. Petridou G. Asclepius the Divine Healer, Asclepius the Divine Physician: Epiphanies as Diagnostic and Therapeutic Tools. In: D. Michaelides (ed.) Medicine and healing in the ancient Mediterranean world, Oxford and Philladelphia, Oxbow books, 2014, pp 297-307.

9. Pottier E. Une Clinique grecque au Ve siècle (vase antique du collection Peytel). Monuments et mémoires de la Fondation Eugène Piot, 13.2. Paris: Ernest Leroux. 1907, pp 149-166.

10. Dasen V. L'aryballe Peytel: le cabinet d'un médecin grec. In: Dasen V. (ed.) La Médecine à L'époque romaine. Quoi de neuf, docteur?, Lyon: Musée gallo-romain,
2010, pp 10-11.

11. Krug A. Doktorspiele? - Der Aryballos Peytel. Boreas, Münstersche Beitrage zur Archäologie 35, 2012, pp 11-23.

12. Savel RH, Munro CL. From Asclepius to Hippocrates: the art and science of healing. Am J Crit Care 2014;23:437-439.

13. Asclepius-Man or Myth. JAMA 2020;323:285.

14. Stampolidis $\mathbf{N} \mathrm{Ch}$, Tassoulas $\mathrm{Y}$ Hygeia. Health, illness, Treatment from Homer to Galen. Athens: Museum of Cycladic Art, 2014.

15. Bliquez L. The Tools of Asclepius. Surgical Instruments in Greek and Roman Times (Studies in Ancient Medicine), Brill Academic Publishers. 2014.

16. Berger E. Das Basler Arztrelief: Studien zum griechischen Grab- und Votivrelief um 500 v. Chr. und zur vorhippokratischen Medizin (Veröffentlichungen des Antikenmuseums Basel, 1), Basel: Philipp von Zabern, 1970.

17. Papavramidou $\mathrm{N}$, Thomaidis $\mathrm{V}$, Fiska A. The ancient surgical bloodletting method of arteriotomy. I Vasc Surg 2011;54:1842-1844

18. Ulvik RJ. Arelatingso Medisinsk Behandling 2500 år (Bloodletting as medical therapy for 2500 years). Tidsskr Nor Laegeforen 1999;119:2487-2489.

19. Koutserimpas C, Alpantaki K, Samonis G. Trauma management in Homer's Iliad. Int Wound J 2017;14:682-684.

20. Koutserimpas C, Samonis G. Letters. J Wound Care 2016;25:553-554. Erratum in: J Wound Care 2017;26:153.

21. Koutserimpas C, Samonis G. Re:
Stathopoulos, et al. Injuries to the head and neck in Homer's Odyssey. Br J Oral Maxillofac Surg 2017;55:217.

22. Koutserimpas C, Samonis G. Machaon: the first trauma surgeon in Western history? J Wound Care 2018;27:659-661.

23. Koutserimpas C, Samonis G. Letter to the editor: Medical structures during war in the Homeric era: paramedics and 'expedition' hospitals. J Wound Care 2017;26:152-153.

24. Dasen V. Dwarfs in Athens. Oxford Journal of Archaeology 1990;9:191-207.

25. Dasen V. Dwarfism in Egypt and classical antiquity: iconography and medical history. Med Hist 1988;32:253-276.

26. Hodges FM. The ideal prepuce in Ancient Greece and Rome: male genital aesthetics and their relation to lipodermos, circumcision, foreskin restoration, and the kynodesme. Bull Hist Med 2001;75:375-405.

27. Pfeiffer KM, Brod M, Smith A, et al. Assessing physical symptoms, daily functioning, and well-being in children with achondroplasia. Am J Med Genet A 2021;185:33-45.

28. Aristophanes. The Acharnians.

29. Aristophanes. "Sfikes" (The Wasps).

30. Cohn-Haft L. The Public Physician of Ancient Greece (Smith College Studies in History, vol. XLII), Northampton, Mass., 1956.

31. Homer. The Iliad.

32. Longrigg J. Greek Medicine from the Heroic to the Hellenistic Age. A Source Book. London-New York: Routledge, 1998.

33. Loomis WT. Wages, Welfare Costs and Inflation in Classical Athens, Ann Arbor, 1998. 